\title{
The influence of corporate social responsibility activities on customer value co-creation: the mediating role of relationship marketing orientation
} responsabilidad social corporativa en la co-creación de valor para el cliente: El papel mediador de la orientación del marketing relacional

Muhammad Mubushar, Norizan Bt Jaafar and Rossazana Ab Rahim Faculty of Economics and Business, UNIMAS, Kuching, Malaysia

\begin{abstract}
Purpose - This paper aims to investigate the impact of external stakeholders-related corporate social responsibility (CSR) activities (local community and suppliers) on customer value co-creation behavior. This study also aims to examine the mediating role of relationship marketing orientation (RMO) on the relationship of CSR activities and customer value co-creation behavior.

Design/methodology/approach - The main problem of dichotomy between customers and the management was existing in banking sector so that's why through purposive sampling, banking customers were selected for data collection through a self-administered questionnaire. Structural equation modeling was used to test the proposed hypotheses.

Findings - The present study found that both local community-related and supplier-related CSR activities have a positive impact on customer value co-creation behavior. Relationship marketing orientation mediates between the link of CSR activities and customer value co-creation behavior. The strength of RMO in CSR supplier and customer value co-creation behavior is found to be more dominant.

Research limitations/implications - This study is restricted to one country under-investigation; therefore, it can be replicated with a larger and more geographically diverse sample.
\end{abstract}

(C) Muhammad Mubushar, Norizan Bt Jaafar and Rossazana Ab Rahim. Published in Spanish Journal of Marketing - ESIC. Published by Emerald Publishing Limited. This article is published under the Creative Commons Attribution (CC BY 4.0) licence. Anyone may reproduce, distribute, translate and create derivative works of this article (for both commercial and non-commercial purposes), subject to full attribution to the original publication and authors. The full terms of this licence may be seen at http://creativecommons.org/licences/by/4.0/legalcode

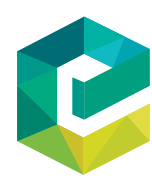

Spanish Journal of Marketing ESIC

Vol. 24 No. 3,2020 pp. $309-330$

Emerald Publishing Limited 2444-9709 DOI 10.1108/SJME-12-2019-0101 
Practical implications - This study offers insights to the banking sector that local community-related CSR activities contribute to the value co-creation behavior and minimize the social problems of Pakistan.

Originality/value - The findings of this study highlight that top management of banks can enhance the customer's participation in services by using valuable CSR activities. The results imply the importance of interactions between the recipient of services and service providers. Stakeholder theory has previously been applied to examine stakeholders' value maximization; this study uses stakeholder theory to examine shareholders' value co-creation.

Keywords Corporate social responsibility, Supplier, Local community

Relationship marketing orientation, Customer value co-creation behavior

Paper type Research paper

\section{Resumen}

Propósito - Este estudio investiga el impacto de las actividades de responsabilidad social corporativa (RSC) relacionadas con las partes interesadas externas (comunidad local y proveedores) en el comportamiento de cocreación del valor del cliente. Este estudio también tiene como objetivo examinar el papel mediador de la orientación del marketing relacional (OMR) en la relación de las actividades de responsabilidad social corporativa y el comportamiento de co-creación del valor del cliente.

Diseño/metodología/enfoque - El principal problema de dicotomía entre los clientes y la gerencia existía en el sector bancario, por lo que a través de un muestreo intencional, los clientes bancarios fueron seleccionados para la recolección de datos a través de un cuestionario auto-administrado. Con el fin de verificar las hipótesis propuestas, se empleó un modelo de ecuaciones estructurales.

Hallazgos - El presente estudio encontró que tanto las actividades de RSC relacionadas con la comunidad local como las relacionadas con los proveedores tienen un impacto positivo en el comportamiento de co-creación del valor del cliente. La orientación del marketing relacional media entre el vínculo de las actividades de responsabilidad social corporativa y el comportamiento de co-creación del valor del cliente. La fuerza de la OMR en el comportamiento de co-creación del valor del cliente y el proveedor de RSC se encontró que era más dominante.

Limitaciones de la investigación - Este estudio se limita a un único país, por lo tanto, podría ser replicado con una muestra más amplia y con mayor diversidad geográfica.

Implicaciones prácticas - Este estudio ofrece información al sector bancario de que las actividades de RSE relacionadas con la comunidad local contribuyen al comportamiento de co-creación de valor y minimizan los problemas sociales de Pakistán.

Originalidad/valor - Los resultados de este estudio ofrecen a la alta dirección de los bancos la posibilidad de mejorar la participación de los clientes en los servicios mediante la utilización de valiosas actividades de RSC. Los resultados implican la importancia de las interacciones entre el receptor de los servicios y los proveedores de servicios. La teoría de las partes interesadas se ha aplicado anteriormente para examinar la maximización del valor de las partes interesadas; este estudio utiliza la teoría de las partes interesadas para examinar la co-creación de valor de los accionistas.

Palabras clave Responsabilidad social corporativa, Comportamiento de co-creación de valor de los clientes, Orientación del marketing de relaciones

Tipo de artículo Trabajo de investigación

\section{Introduction}

In rapidly changing environment, customers have transformed their traditional role and looking for customized products/services with the ease of information, awareness and technology (Wu et al., 2016; Kumar et al., 2018). In this scenario, relationship building with stakeholders such as customers remains the core activity of any company (Royle and Laing, 2014; Kumar et al., 2018), and corporations are under high stress to discover new methods of participation in defensible development and meeting ethical expectation.

To meet this challenge, one platform is corporate social responsibility (CSR) on which a corporation can reflect stakeholders' orientation to address special issues (Planken et al., 2013; Rosa et al., 2017). CSR is: 
[...] the commitment of business to act ethically and contribute to the development of the economy while improving the quality of life of the employees, their families, customer, and local community as well as society at large (Watts, 2000).

Due to its significant impact on firms' efficiency and performance (Benlemlih and Bitar, 2018), CSR has become an international agenda for corporations as well as public and private institutions (Ruiz-Alba et al., 2014; Terrero-De La Rosa et al., 2017). Therefore, 90\% of the top 250 largest companies in the world are investing in socially responsible activities and published their CSR reports (KPMG, 2015). European cluster (Eastern Europe, Continental Europe, British Isles, Northern Europe and Mediterranean Europe) has also developed 499 CSR initiatives with the help of the best 178 leading member corporations of European business networks (Maon et al., 2017). Even though it is largely acknowledged that CSR is a product of Western countries, but it has gained a significant amount of attention in the Asian region, both in the corporation and academia (Fifka, 2012). Reporting of CSR investment has increased up to $50 \%$ in Asia especially in Indonesia and Malaysia (KPMG, 2016; Arena et al., 2018).

After introducing mandatory CSR investment and discloser by the Security Exchange of Pakistan in 2013, most Pakistani industries are catching up with their counterparts in developed countries in terms of their CSR initiatives (Chaudary et al., 2016; Syed and Butt, 2017). The banking industry of Pakistan is deeply involved in CSR activities by improving electronic banking, investing in various social NGOs and contributing to the betterment of human beings (Khan et al., 2014). Bank Al Habib donated Rs. 159.8m to underprivileged people for health, education, social and welfare development. MCB bank is one of the market leaders in the entire banking sector to serve the internal and external stakeholders including the community (Arifeen, 2018). Currently, most Pakistani banks have included CSR in their mainstream strategies. Despite their significant effort, CSR is unnoticed by customers due to the lack of engagement between stakeholders, and this problem has widened the gap between the customers and the management of the banks (Yunis et al., 2017; Khan et al., 2014). This is one of the main reasons that CSR in Pakistan is underexplored (Bagh et al., 2017; Ashraf et al., 2017). To address this issue, research scholars and practitioners have conducted in-depth studies on CSR activities to learn the changing role of customers in the complex environment of banking (Oberseder et al., 2014; Li et al., 2017) but could not create consensus. Similarly, some recent developments have created crisis in banking industry of Pakistan. For example, Federal Investigative Agency (FIA) issued a list of 400 most powerful personalities and bankers who were involved to move 200 billion rupees from factious bank accounts and products. Along with this, a huge amount was stolen from the customers' accounts through phone calls and Web links by fraudsters (Pakistan Today, 2018: ProPakistani, 2019). The regulatory bank has charged penalties worth Rs. $773 \mathrm{~m}$ on nine major banks in August 2019 for breaking the rules and regulations. All these fresh incidents have badly shaken the confidence of customers, and they are less convinced to use the banking channels. They leave the banks and move toward cash-based transactions which explains Pakistan's 36\% undocumented economy (Mangi, 2012). Thus, the current study attempts to explore the relationship between CSR activities and customer value cocreation in banking industry of Pakistan to understand the changing behavior of customers. The outcomes of study would help to minimize the gap between the customers and the management.

Furthermore, consumer's perspective is less explored (Lee et al., 2011; Bolton and Mattila, 2015) and prior research related to CSR focuses mainly on the relationships of CSR and behavioral consequences of customers such as the impact of CSR on customer loyalty (Pérez and Rodríguez del Bosque, 2017; Fatma et al., 2018; Ajina et al., 2019; Mohammed and A1-

\author{
Role of \\ relationship \\ marketing \\ orientation
}

311 
Swidi, 2019). Many scholars have explored the role of CSR in purchase intentions, the impact of CSR and customer preferences and customers' reactions (Lee and Lee, 2018; Bae et al., 2019; Tingchi Liu et al., 2014; Anadol et al., 2015). Yet, the concept of CSR and customer value co-creation behavior are still underexplored (Dechiara, 2012; Ahen and Zettinig, 2015; Luu, 2019). CSR must be conducted based on other customers' behavioral aspects because customers are changing their traditional and passive role as a merely recipient of services/ products to being an active participant in value co-creation: customer participation behavior and customer citizenship behavior (Vargo and Lusch, 2014; Yi and Gong, 2013; McCollKennedy et al., 2012). Research have been conducted to study the importance of customer involvement in social responsibility, and it was found that value co-creation behavior is essential to meet the changing dimensions of a marketplace in the contemporary world (Ida, 2017; Wagner, 2017). However, there are extremely limited research on the effects of CSR dimensions on customer value co-creation.

Moreover, the researchers seek to find a mechanism that links relationship marketing orientation (RMO) with CSR activities and customer value co-creation behavior. For effective value co-creation, interface is very important between customers and service providers (Vargo and Lusch, 2008). RMO relationship activities for the interest of customers and cocreates values through reciprocal contribution (Gruen et al., 2000). RMO is also a further investment of companies for the development of a long-term relationship with stakeholders (Knox and Gruar, 2007). In this way, RMO can serve as a mediator between CSR actions and customer value co-creation behavior.

This study has three contributions: the first and foremost is academic contribution. Based on stakeholder theory, this study extends the literature of CSR to customer value cocreation behavior. This adds on to the existing body of literature that only links CSR with customers passive outcomes such as loyalty, purchase intentions and repurchase intentions (Lee and Lee, 2018; Bae et al., 2019). The current study will break the concept of CSR into dimensions, namely, CSR local community and CSR suppliers, and highlight their roles in customer value co-creation behavior. Second, this study emphasizes on the indirect role of RMO between CSR activities and customer value co-creation behavior to build the qualityoriented relationship between customers and service providers.

The final contribution is that this study applied stakeholder theory highlight on noneconomic value of stakeholders, while most studies on CSR use stakeholder theory to maximize the value of shareholders (Harrison and Wicks, 2013). This is the first study which uses this theory and explores the relationship between CSR dimensions and customer value co-creation behavior.

\section{Literature review}

\subsection{Local community-related corporate social responsibility activities and customer value co-creation behavior}

Companies have plentiful resources to bring prosperity for the community; therefore, CSR is considered to be a very important mechanism to strengthen the link between corporations and the local community for the economic stability of the society in the longer run (NEAC, 2010). CSR campaigns enable communities to be more than just a market in the eyes of business; therefore, corporations ought to understand which CSR activities are closely aligned with the community when planning CSR strategies. Local community-related CSR is a set of philanthropic activities which brings improvements in the community in terms of employment, health, education, water supply, sanitation, etc. (Maloni and Brown, 2006; Aguilera et al., 2007; Ismail et al., 2015). Customers are likely to observe the tangible features of firms that encourage their participation. Thus, they tend to respond positively to 
community-orientated projects that are closely linked with customers (Marquina Feldman and Vasquez-Parraga, 2013).

Understanding the customers' response to stakeholders-oriented CSR activities, many scholars proposed that well-executed community-related CSR programs may enhance customer based behavioral outcomes (Halkias et al., 2013; Tingchi Liu et al., 2014; Pérez and Rodriguez del Bosque, 2015). If a vigorous relationship has been found between communityoriented CSR activities and its positive consequences, then studies must be able to check the relationship between local community CSR and more specific aspects of customers such as customer value co-creation behavior because following service-dominant logic, customers are always operant resources for value co-creation (Vargo and Lusch, 2004; Vargo and Lusch, 2008). Customers have changed their traditional passive role in services as they are not only demanding services but also tend to participate actively by a unique alliance between companies and customers (Zhang et al., 2015; Rialti et al., 2018). A number of scholars proposed that philanthropic activities create the added value for the community as well as for the company because its altruistic values give a sense of connection and identification to the customers (Sen et al., 2006; Pérez and Rodriguez Del Bosque, 2015). When they perceive the value to be close to their own identities, they are more likely to share their values. However, these are just assumption as the relationship between CSR activities and customer value co-creation value is limitedly explored (Laczniak and Murphy, 2006; Ahen and Zettinig, 2015; Luu, 2019).

Thus, the current study seeks to test the relationship between local community-oriented CSR activities and customer value co-creation behavior. This behavior is the combination of dual factors: customer participation behavior such as information seeking, information sharing, responsible behavior and personal interaction and customer citizenship behavior which include giving feedback, showing advocacy, helping and being tolerant (Yi and Gong, 2013). With the help of community members' understanding of the customers' participation, prospects can be improved (Kamboj and Rahman, 2017; Sanclemente-Téllez, 2017; Bharti et al., 2014). Similarly, customers have a high tendency to demonstrate extra-role behavior that is the customer citizenship behavior if they perceive that the company is more ethical and interdependent on society's welfare (Karaosmanoglu et al., 2016). This leads to the following hypothesis:

H1. Local community-related CSR activities positively affect (a) customer participation behavior and (b) customer citizenship behavior.

\subsection{Supplier-related corporate social responsibility activities and customer value co-creation behavior}

To become socially responsible, firstly a company needs to be a good partner to its good business partner. A firm can force its business suppliers to improve the prospects of products/services by educating about quality goals as per adopted standards and mutually agreeing on quality control procedures (Longo et al., 2005). Focusing on the labor standard of business partners and other business suppliers in compliance with legalities as well as executing procedures for them is seen as part of CSR practices within the corporations (Graafland and van de Van, 2006; Skudiene and Auruskeviciene, 2012). It means all the CSR activities consisting of fair dealings with suppliers and other business partners fall under the category of supplier-related CSR.

CSR has been gaining the utmost importance in the domain of supply chain management, and most of the companies are keeping the element of CSR into their account when purchasing from their suppliers (Maignan et al., 2002; Kolk and Van Tulder, 2002). 
SJME

24,3

314

One of the primary motives behind this is the pressure from customers who tend to be concerned with the suppliers of the corporation (Bartley, 2007). A firm directly or indirectly uses the suppliers' products as its end-products; therefore, customers' perceptions may be affected by the activities of the suppliers (Hietbrink et al., 2010). Thus, it is argued that customers' concerns can be addressed in suppliers' CSR activities. To support this argument, many scholars asserted that customer demand, personal conviction and ethical obligation can be addressed into supplier-related CSR activities (Carter and Jennings, 2004; De Ruyter et al., 2009). A large number of CSR studies have demonstrated that addressing the customers' concerns into CSR communications corporations can influence the behavioral intentions of customers. For example, CSR activities related to customers' concerns is more related to customers trust as compared to others which generate behavioral loyalty due to being directly connected with the customers' needs (Mandhachitara and Poolthong, 2011; Chung et al., 2015; Tingchi Liu et al., 2014; Badenes-Rocha et al., 2019). Corporations often try to incorporate customers' self-centered motives on a personal level in their strategies to influence their buying behavior. Recent studies found links between these two wellestablished concepts (Laczniak and Murphy, 2006; Ahen and Zettinig, 2015; Luu, 2019). Customer value co-creation behavior is twofold: customer participation behavior and customer citizenship behavior (Yi and Gong, 2013). By incorporating customers' needs into mainstream strategies, companies can influence the factors of participation behavior for value co-creation (Bharti et al., 2014; Ida, 2017; Zhao et al., 2018). Similarly, researchers have suggested that CSR influences customer citizenship behavior (Lee and Yoon, 2018; Van Tonder and Petzer, 2018). Based on stakeholder theory and the above-mentioned premise, the following hypothesis is formed:

H2. Supplier-related CSR activities positively affect (a) customer participation behavior and (b) customer citizenship behavior.

\subsection{Relationship marketing orientation as a mediator between local community-related corporate social responsibility activities and customer value co-creation behavior}

Customers are the operant resources or source of knowledge and skills for value co-creation (Vargo and Lunch, 2004). For effective value co-creation, interaction between consumers and service providers is necessary (Vargo and Lusch, 2008). This point highlights how RMO deepens the facets of CSR and customer value co-creation behavior under the stakeholder theory. According to this bilateral relation, customers must be a fundamental operant resource for value co-creation behavior (Vargo and Lusch, 2004; Gohary and Hamzelu, 2016). It can be argued that relational activities and interaction can convert customers into dynamic operant resources for corporations (Vargo and Lusch, 2011; De Chiara, 2012). Consequently, this type of planned orientation can tighten the relationships between corporations and customers (Morgan and Hunt, 1994) and ensure that maximum benefits are reap by the customers from CSR activities (Gohary and Hamzelu, 2016).

When a company engages local community-oriented CSR, it builds relationships with customers due to positive evaluation which further extends trust, respect and care to customers (Tse et al., 2004). Once customers evaluate a corporation positively, they are committed for exchange including value co-creation. Through CSR activities, customers will notice that the corporation shares a common goal and values with them which help to enhance their connection with the socially responsible organization for value co-creation through communication (Abugre and Nyuur, 2015). The element of empathy in RMO also differentiates the socially responsible organization in the eyes of the customer (Tse et al., 2004). Reciprocity is the element of RMO which enables customers to collaborate and 
respond to the organization (Jayachandran et al., 2005). All six dimensions of RMO play a significant role in linking CSR community and customer value co-creation behavior. It can be assumed that RMO may serve as a mediator between CSR community and customer value co-creation behavior. This leads to the third hypothesis, which is:

H3. RMO is a positive mediator between local community-related CSR activities (a) customer participation behavior and (b) customer citizenship behavior.

\subsection{Relationship marketing orientation as a mediator between supplier-related corporate social responsibility activities and customer value co-creation behavior}

In mainstream marketing studies, the literature on relationship marketing has ignored the importance of the other stakeholders besides customers. Thus, in relationship marketing approach, there is a growing consensus to focus on other stakeholders, along with customers, in the network (Payne et al., 2005; Gummesson, 1999). Relationship marketing focuses on how to create ongoing value-in-use, as opposed to only considering how to build relationships with customers (Payne and Frow, 2017). Relationship marketing orientation can be defined as the degree to which a firm is involved in developing long-term relationships with its clients (Tse et al., 2004). Sin et al. (2005) elaborated relationship marketing orientation (RMO) in more detail: trust, communication, empathy, shared value, reciprocity and bonding.

Trust explains the preparedness to have faith in a partner on which a person can rely on with confidence (Morgan and Hunt, 1994). The communication facet refers to the sharing of official or unofficial timely and meaningful information between buyers and sellers. The element of empathy allows a person to see a situation from the stance of other people. The fourth is shared values which explain the extent to which partners believe commonly in policies, behavior and appropriateness (Morgan and Hunt, 1994). Reciprocity highlights a process that helps the customer to relate and share data within the organization and enable it to respond to the consumers' needs (Jayachandran et al., 2005). The last facet is bonding: that discusses emotional improvement between two bodies that act in unified manners for a common cause (Sin et al., 2005). The tendency of the relationship in CSR suppliers and customer value co-creation might be intensified by the related actions of the organization and in this way, RMO may serve an influencer. Relationship marketing orientation can help to drive the suppliers to further connect with the organization and its CSR value and stimulate the customer for active participation in the entire process (McColl-Kennedy et al., 2012; Tse et al., 2004). The RMO is a further investment of corporations to strengthen the bonding with consumers for value co-creation that is also a form of reciprocity which is the outcome of relationship strategy (Tse et al., 2004). Every facet of RMO further encourages customers' perceptions about the CSR values of the organization which eventually leverage the reciprocal contribution from the customers in terms of value co-creation behavior. Thus, it is suggested that relationship marketing orientation can play a role as an intermediary force between suppliers-related CSR activities and customer value co-creation behavior (Figure 1).

H4. RMO positively mediates between suppliers-related CSR activities (a) customer participation behavior and (b) customer citizenship behavior.

\section{Data collection and methodology}

This research is conducted using cross-sectional survey to test the proposed relationships in the model based on the stakeholder theory. The primary data is gathered from the customers of twin cities Rawalpindi/Islamabad who maintain their accounts in the Pakistani

\section{Role of relationship \\ marketing orientation}


Figure 1.

Theoretical framework: the relationship of corporate social responsibility (CSR) activities, customer value co- creation behavior and relationship marketing orientation

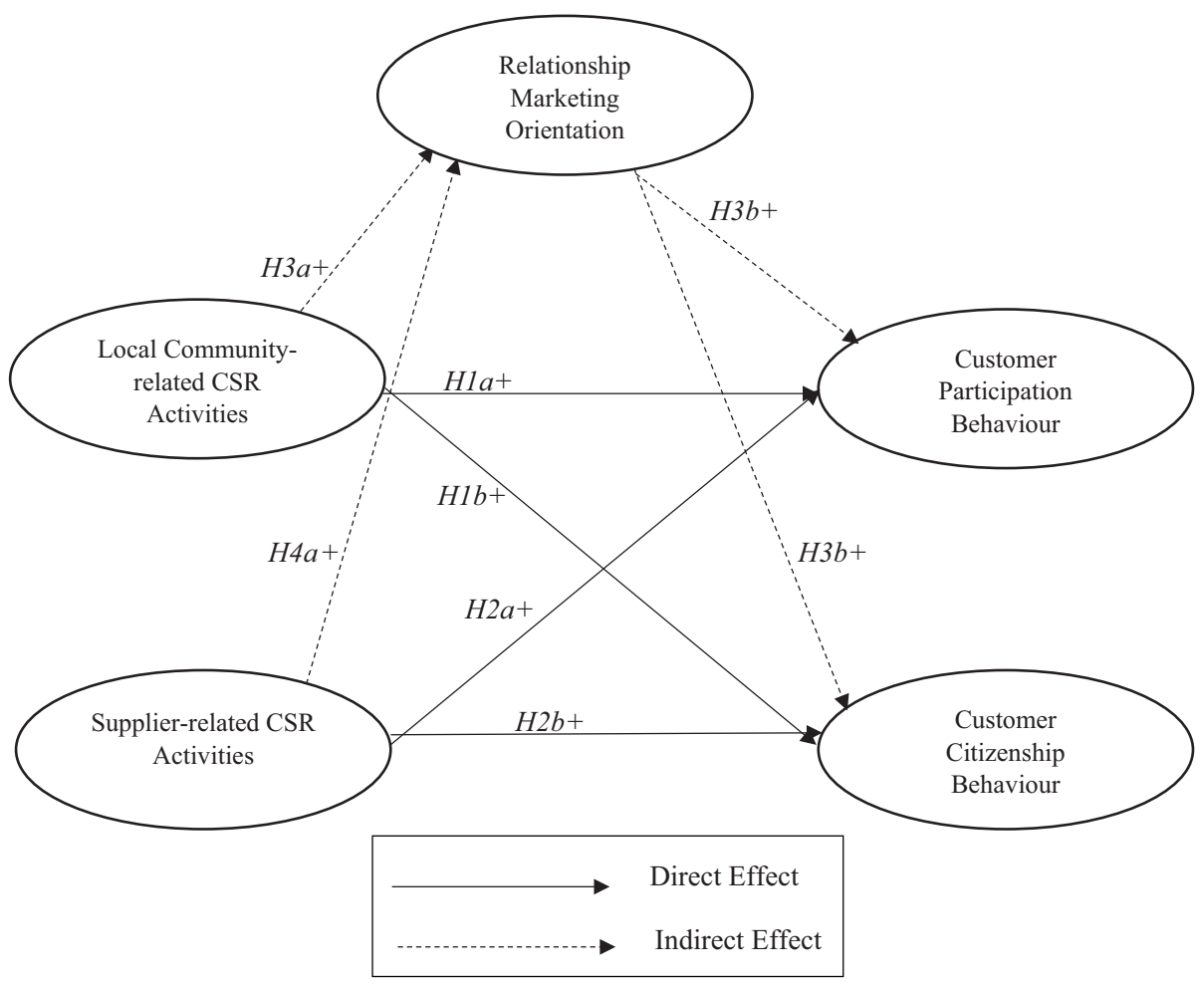

banking industry. Islamabad is the capital of Pakistan and mixture of all societies due to educational hub and higher opportunities which is the best representative of Pakistani society. These responses gathered from banking industry as the problem of the disconnection between customers and management happen in this industry (Mujahid and Abdullah, 2014; Khan et al., 2014). To analyze the data, Smart PLS is used because the data fulfilled the assumptions of Smart PLS such as the sample size, etc. Although structural equation modeling can be run using a small sample size such as between 150 to 200 respondents, large sample size helps to establish better results (Hair et al., 2014) and the sample size of the present study fell beyond the recommended limit. In Pakistan, there are 34 operating banks (State Bank, 2016), and it is not possible to collect the data of all banks. These banks are categorized into three levels: small, medium and big banks based on market share, size, and total deposits. The researchers selected ten medium-size banks to be included in this study because these banks are more customer-oriented and strive to capture more market share (KPMG, 2015). This is because small size banks have less number of branches and cover limited geographical areas, while big banks have already huge share and are not aggressively customer-centric compared to medium size banks. The respondents are selected using purposive sampling. In Pakistan, only $16 \%$ of the total population have bank accounts (State Bank of Pakistan, 2016). The total population of Pakistan is 207 million (Pakistan Bureau of Statistics, 2017; Shahbaz, 2017), and the total banking customers are 30.1 million. Krejcie and Morgan (1970) suggested that if the population is more than 1 million, a sample size of 384 respondents is adequate. As much as 
550 questionnaires are distributed in twin cities, Rawalpindi and Islamabad. As much as 395 are returned but only 384 responses are inputted in SPSS 11 as the other questionnaires were half-filled. Data was checked through SPSS which is normal and through descriptive statistics we check the numbers, and valid percentage in frequency which shows that there is no missing value. The response rate was $71.8 \%$ that is similar to many studies conducted in Asia (Raja et al., 2004; Abbas et al., 2014). As much as 274 questionnaires, out of 384, were filled by males and 110 were filled by females and their proportion is 71.35 and $28.6 \%$, respectively. In Pakistan, males are responsible to run the families' expenses; hence, there are more male bank users compared to females. Therefore, the disproportionate ratio between males and females respondents is appropriate in this context. There were 96 respondents between 18 and 24 years old (25\%), 133 are 25 to 31 years old (34.6\%), 87 are 32 to 38 years old (22.7\%), 59 are 39 to 54 years old (15.4\%) and 9 are 55 to 60 years old $(2.3 \%)$. As for educational level, 227 respondents have bachelor's degree (59.1\%), 146 have a master's degree (38.0\%), 10 have a MPhil $(2.6 \%)$ and 1 have a $\mathrm{PhD}(0.3 \%)$. Mostly in banks, customers are educated and use digital services such as mobile, SMS and internet services. Second, Islamabad and Rawalpindi have the highest literacy rate. Therefore, mostly respondents are educated. Seventy eight respondents maintain their account in The Bank of Punjab (20.3\%), 53 in Faisal Bank (13.8\%), 53 in Askari Bank (13.8\%), 49 in Habib MetroPolitian Bank (12.8\%), 46 customers maintain their account in Bank Al-Habib (12.0\%), 39 in Meezan Bank (10.2\%), 32 in Standard Charted Bank (8.3\%), 24 in NIB bank (6.3\%)and 10 in Soneri bank $(2.6 \%)$.

\subsection{Measurement of instrument}

The scales consist of five-point Likert items that ranged from strongly disagree to strongly agree. Five-item scale measured the independent variable - CSR local community, and a four-item scale measured the independent variable - CSR Suppliers. Six dimensions of relationship marketing orientation, namely, reciprocity, communication, bonding, empathy, trust and shared value, are measured by a 22 -items scale. Two dimensions of customer value co-creation behavior, the dependent variable; customer participation behavior and customer citizenship behavior are measured by a 30 -item scale. The scales for measuring the variables are adapted from literature which is given in the following table. In scale, the statement of items exactly measures the dimensions of CSR, relationship marketing and customer value co-creation behavior. For example, "My bank is supporting local sport, cultural or other community activities and projects" measure the local community-related CSR. Similarly, "My bank incorporates the interests of their suppliers in their business decisions" related exactly measure supplier-related CSR. Other scales are also assessed in this way, and these scales are validated by multiple scholars. The CSR activities-related scales have been tested in banking sector by Pérez and del Bosque (2013). Similarly, relationship marketing orientation and customer value co-creation scales are validated by Mainardes et al. (2017) (Table 1).

\section{Results and discussion}

\subsection{Measurement model}

To test the theoretical model, the first step is measurement model which is known as outer model. From the very beginning, it is mandatory to check whether the constructs are formative or reflective. The evaluation criteria of the formative measurement model were different from the reflective measurement model (Hair et al., 2014). In the formative measurement model, internal consistency is not appropriate (Chin, 1998), due to the representation of the independent cause and having no correlation with each other. The

\section{Role of relationship marketing orientation}

317 


\begin{tabular}{llll}
\hline Variable type & Variable & Definition & Source \\
\hline Independent & $\begin{array}{l}\text { CSR Local } \\
\text { community }\end{array}$ & $\begin{array}{l}\text { Local community-related CSR is a set } \\
\text { of philanthropic activities which } \\
\text { brings improvements for the }\end{array}$ & $\begin{array}{l}\text { Pérez and del } \\
\text { Bosque (2013) }\end{array}$
\end{tabular}

\section{8}

CSR suppliers

\section{Table 1.}

Scales and sources:

CSR activities scales, relationship

marketing

orientation scale, customer value $\mathrm{Co}$ creation scale

$\begin{array}{ll}\text { Mediator } & \begin{array}{l}\text { Relationship } \\ \text { marketing orientation }\end{array} \\ \text { Dependent variable } & \begin{array}{l}\text { Customer } \\ \text { participation } \\ \text { behavior }\end{array} \\ & \begin{array}{l}\text { Customer citizenship } \\ \text { behavior }\end{array}\end{array}$

community in term of employment, health, quality education, water, and sanitation

Focusing on the labor standard of business partners and other business suppliers in compliance with legalities as well as executing procedures for them is seen as part of CSR practices within the corporations The degree in which an organization involves for the development of longlasting ties with its clients

It caters responsible behavior, information seeking, personal interaction, and information sharing sub-dimensions

It caters tolerance, feedback, helping and advocacy dimensions

\author{
Sin et al. (2005) \\ Yi and Gong (2013) \\ Yi and Gong (2013)
}

Cochius (2013)

reflective measurement model's items must be correlated and depict the true picture of the significant outer loadings. The reflective measurement model needs reliability and validity of construct, whereas formative measurement model needs convergent validity and discriminant validity. In the current study, all variables are reflective. Table 2 describes the composite reliability of the variables The value falls between the range of 0 and 1 where higher values of composite reliability describe higher reliability and the acceptable values fall between 0.60 and 0.70 (Gefen et al., 2000). Memon et al. (2018) proposed that 0.70 is considered as the standard for consistency.

Table 4.1 shows that the value of composite reliability for all variables is above 0.70 that shows that all items are internally consistent. Outer loading indicates the reliability that shows the indent of measurement which is actually being assessed (Urbach and Ahlemann, 2010). The cut-off value for reliability is 0.50. This table also shows the AVE which is greater than 0.50 for all variables which shows that every variable must explain a minimum of $50 \%$ of the variance by the assigned items (Hair et al., 2017).

Table 3 shows the discriminant validity and in the present study, the criteria outlined by Fornell and Larker (1981) are being followed where the squired root of the AVE on the diagonal must be more than the correlation on the off-diagonal. The following table describes that the values of all constructs are greater than off-diagonal values which means that there is no issue of discriminant validity (Figure 2).

\subsection{Mediation analysis}

Table 4 explains the direct relationship of CSR activities on customer participation behavior and customer citizenship behavior. Local community-oriented CSR activities positively affect customer participation behavior as its t-values is 7.777 which is greater than 1.645 and significant at 0.05 level. Local community-oriented CSR also positively affects customer citizenship behavior and its t-values is 4.798 which is greater than 1.645 and significant at 


\begin{tabular}{|c|c|c|c|c|c|}
\hline Constructs & Items & O.L & $\mathrm{CR}$ & AVE & Role of \\
\hline \multirow[t]{4}{*}{ CSR local community } & CSRE1 & 0.770 & \multirow[t]{4}{*}{0.806} & \multirow[t]{4}{*}{0.51} & morlicting \\
\hline & CSRE2 & 0.730 & & & marketing \\
\hline & CSRE3 & 0.725 & & & orientation \\
\hline & CSRE4 & 0.706 & & & \\
\hline \multirow[t]{4}{*}{ CSR suppliers } & CSRS1 & 0.790 & \multirow[t]{4}{*}{0.823} & \multirow[t]{4}{*}{0.527} & \\
\hline & CSRS2 & 0.713 & & & \\
\hline & CSRS3 & 0.744 & & & 319 \\
\hline \multirow{2}{*}{\multicolumn{6}{|c|}{ RMO }} \\
\hline & & & & & \\
\hline \multirow[t]{4}{*}{ Trust } & TR1 & 0.807 & \multirow[t]{4}{*}{0.858} & \multirow[t]{4}{*}{0.602} & \\
\hline & TR2 & 0.785 & & & \\
\hline & TR3 & 0.723 & & & \\
\hline & TR4 & 0.786 & & & \\
\hline \multirow[t]{4}{*}{ Bonding } & BO1 & 0.747 & \multirow[t]{4}{*}{0.817} & \multirow[t]{4}{*}{0.528} & \\
\hline & $\mathrm{BO} 2$ & 0.763 & & & \\
\hline & $\mathrm{BO} 3$ & 0.766 & & & \\
\hline & $\mathrm{BO} 4$ & 0.724 & & & \\
\hline \multirow[t]{3}{*}{ Communication } & COM1 & 0.790 & \multirow[t]{3}{*}{0.839} & 0.635 & \\
\hline & $\mathrm{COM} 2$ & 0.768 & & & \\
\hline & COM3 & 0.830 & & & \\
\hline Empathy & EM1 & 0.795 & 0.837 & 0.566 & \\
\hline & EM2 & 0.785 & & & \\
\hline & EM3 & 0.807 & & & \\
\hline & EM4 & 0.801 & & & \\
\hline Shared value & SV1 & 0.775 & 0.769 & 0.527 & \\
\hline & SV2 & 0.732 & & & \\
\hline & SV3 & 0.674 & & & \\
\hline Reciprocity & RE1 & 0.710 & 0.791 & 0.558 & \\
\hline & RE2 & 0.779 & & & \\
\hline & RE3 & 0.750 & & & \\
\hline Information seeking & INSE1 & 0.715 & 0.799 & 0.570 & \\
\hline & INSE2 & 0.776 & & & \\
\hline & INSE3 & 0.777 & & & \\
\hline Information sharing & INSH1 & 0.708 & 0.826 & 0.542 & \\
\hline & INSH2 & 0.729 & & & \\
\hline & INSH3 & 0.786 & & & \\
\hline & INSH4 & 0.721 & & & \\
\hline Responsible behavior & RB1 & 0.775 & 0.828 & 0.547 & \\
\hline & RB2 & 0.786 & & & \\
\hline & RB3 & 0.756 & & & \\
\hline Personal interaction & PI1 & 0.877 & 0.874 & 0.582 & \\
\hline & PI2 & 0.784 & & & \\
\hline & PI3 & 0.737 & & & \\
\hline & PI4 & 0.835 & & & \\
\hline & PI5 & 0.778 & & & \\
\hline Advocacy & $\mathrm{AD} 1$ & 0.824 & 0.851 & 0.655 & \\
\hline & $\mathrm{AD} 2$ & 0.839 & & & \\
\hline & AD3 & 0.763 & & & \\
\hline Feedback & FB1 & 0.733 & 0.828 & 0.617 & \\
\hline & FB2 & 0.828 & & & \\
\hline & FB3 & 0.793 & & & \\
\hline Helping & $\mathrm{H} 1$ & 0.731 & 0.843 & 0.574 & \\
\hline & $\mathrm{H} 2$ & 0.828 & & & \\
\hline & H3 & 0.785 & & & \\
\hline & $\mathrm{H} 4$ & 0.683 & & & \\
\hline Tolerance & TO1 & 0.843 & 0.852 & 0.657 & \\
\hline & TO2 & 0.798 & & & \\
\hline & TO3 & 0.791 & & & \\
\hline & d cornora & lity CSk & ed cornt & & Table 2 . \\
\hline $\begin{array}{l}\text { Notes: } \text { TSRLC = }=\text { trust }, \mathrm{BO}=\text { bor } \\
\mathrm{TR}\end{array}$ & $\begin{array}{l}\text { d corpora } \\
\text { municatic }\end{array}$ & $\begin{array}{l}\text { ity, } \mathrm{CSh} \\
\mathrm{SV}=\mathrm{s}\end{array}$ & $\begin{array}{l}\text { ed corp } \\
\text { recipro }\end{array}$ & Ibllity, & Outer loading, \\
\hline seeking, INSH = infor & $=$ respor & $=$ persol & $=$ advo & $\mathrm{x}, \mathrm{H}=$ & reliability and AVE \\
\hline helping, $\mathrm{TO}=$ toleranc & & & & & \\
\hline
\end{tabular}


SJME

24,3

320

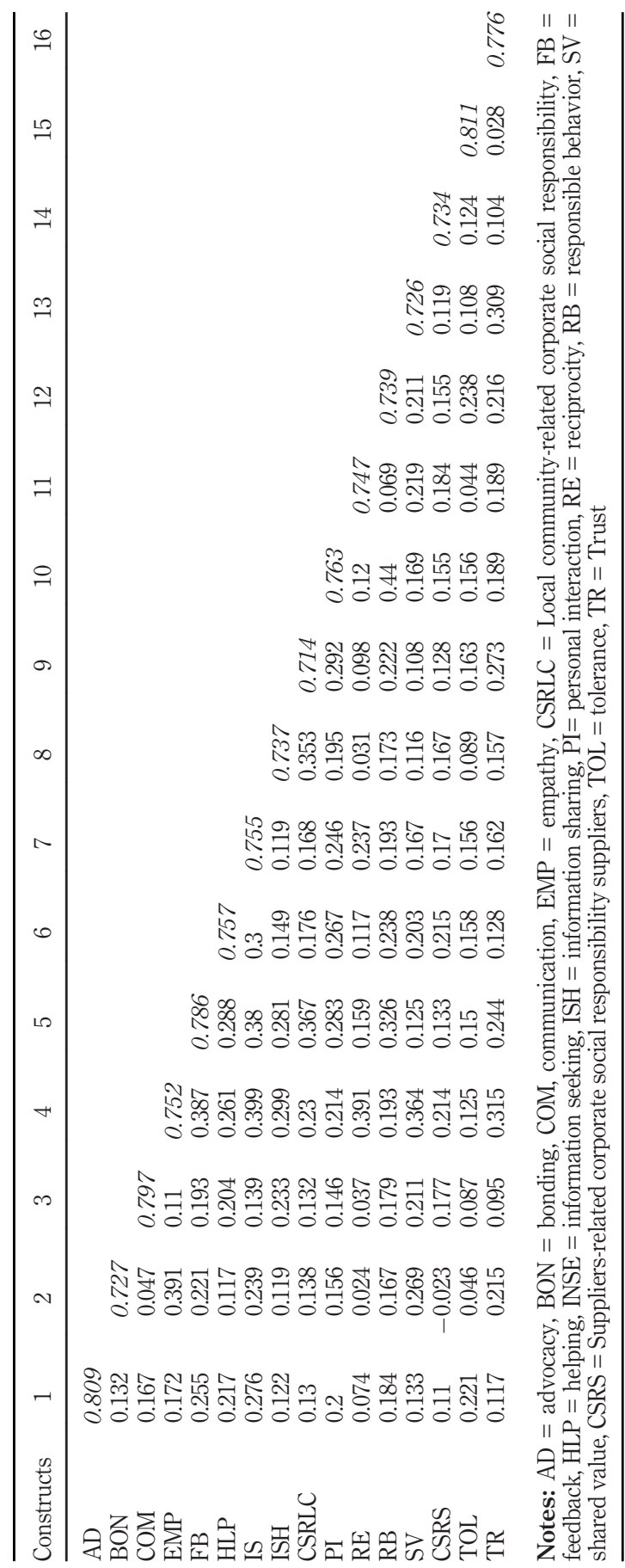

Table 3.

Discriminant validity of constructs 
0.05 level. The beta value is 0.390 and 0.337 for customer participation behavior and customer citizenship behavior, respectively. These beta values describe that if one-unit change occurs in local community-oriented CSR, there will be $39 \%$ change in customer participation behavior and 33\% change in customer citizenship behavior. Supplier-oriented CSR positively affects the customer citizenship behavior as its t-values, 4.035, which is greater than1.645 and significant at 0.05 level. Supplier-oriented CSR also positively affects customer citizenship behavior as its t-values, 3.239, which is greater than 1.645 and significant at 0.05 level. The beta value of supplier-oriented CSR is 0.199 and 0.183 for customer participation behavior and customer citizenship behavior respectively. These beta values describe that 1 unit change in supplier-oriented CSR brings 19\% change in customer participation behavior and $18 \%$ change in customer citizenship behavior.

The $R^{2}$ values are 0.272 and 0.182 which describe that two independent constructs, namely, CSR local community and CSR suppliers explain $27 \%$ variation in customer participation behavior and $18 \%$ variation in customer citizenship behavior. This table also highlights the effect size of both independent variables as the value of $\mathrm{f}^{2}$ shows that local community-oriented CSR has 0.190 and 0.133 effect size for customer participation behavior and customer citizenship behavior, whereas the value of $\mathrm{f}^{2}$ shows that supplier-oriented CSR has 0.049 and 0.039 effect size for customer participation behavior and customer citizenship behavior. Suppliers-related CSR activities have a smaller effect on customer value co-creation behavior as compared to local community-oriented CSR activities. So, H1a, H1b, $H 2 a$ and $H 2 b$ are supported (Figure 3 ).

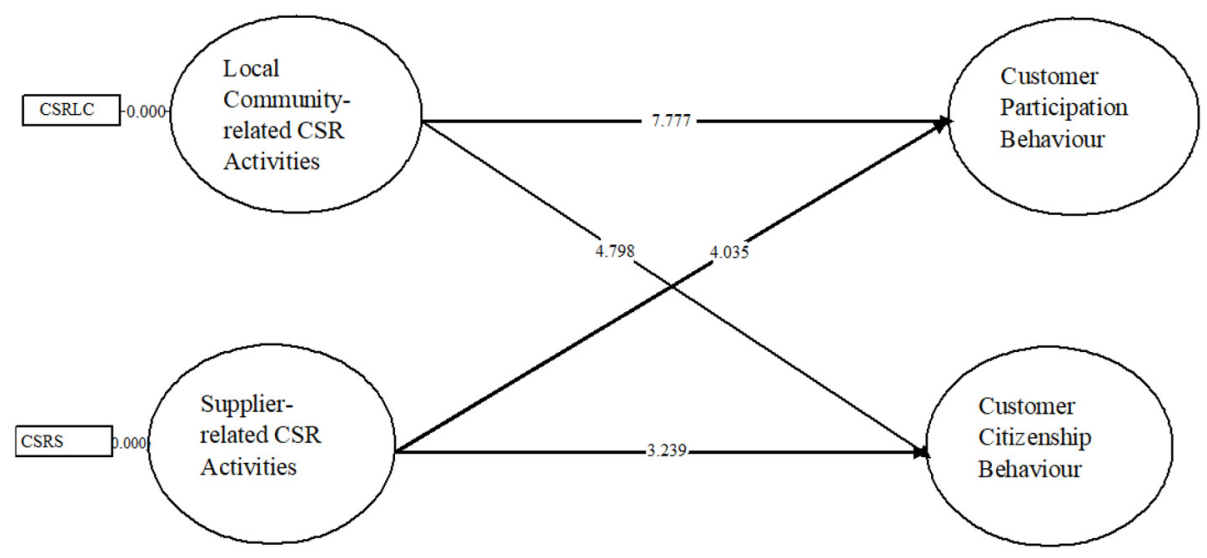

\begin{tabular}{llcccccr}
\hline & Direct hypotheses & $\beta$ & SD & $t$-value & $R^{2}$ & $f^{2}$ & \\
\hline$H 1 a$ & CSRLC $\rightarrow$ CPB & 0.390 & 0.050 & 7.777 & 0.272 & 0.190 & Supported \\
$H 1 b$ & CSRLC $\rightarrow$ CCB & 0.337 & 0.070 & 4.798 & & 0.133 & Supported \\
$H 2 a$ & CSRS $\rightarrow$ CPB & 0.199 & 0.049 & 4.035 & 0.182 & 0.049 & Supported \\
$H 2 b$ & CSRS $\rightarrow$ CCB & 0.183 & 0.056 & 3.239 & & 0.039 & Supported
\end{tabular}

Notes: CSRLC = Local Community-oriented corporate social responsibility, CSRS = Supplier-oriented corporate social responsibility, $\mathrm{CPB}=$ customer participation behavior, $\mathrm{CCB}=$ customer citizenship behavior

\section{Role of relationship marketing orientation}

321
Figure 2.

Direct effect of local community-related and suppliers-related

CSR activities on customer value cocreation behavior
Table 4.

The direct effect of CSR activities on customer value cocreation behavior 
SJME

24,3

\section{2}

Figure 3.

Mediation model: the relationship of corporate social responsibility (CSR) activities, customer value co- creation behavior and relationship marketing orientation
Table 5 describes the direct and indirect impact of local community-oriented CSR and supplier-oriented CSR on customer value co-creation behavior via RMO. The beta value of $H 3 a, H 3 b, H 4 a$, and $H 5 b$ are $0.276,0.240,0.128$ and 0.114 , respectively. The direct effects are statically significant as its $t$-values are above 1.64 (Hair et al., 2017). The beta value of $H 3 a$, $H 3 b, H 4 a$ and $H 4 b$ are $0.102,0.093,0.075$ and 0.069 in the in-direct effect are statistically significant as its values are greater than 1.64 (Hair at el., 2017). It means that relationship marketing orientation partially mediates CSR activities and customer value co-creation behavior. The beta values $H 3 a, H 3 b, H 4 a$ and $H 4 b$ decreased from $0.276,0.240,0.128$ and 0.114 to $0.102,0.093,0.075$ and 0.069 in the in-direct effect, respectively. So $H 3 a, H 3 b, H 4 a$ and $H 4 b$ are supported.

Table 6 highlights the strength of mediation between CSR activities and value cocreation. If a direct link is not significant, then there is no mediation and if a direct link is significant, the VAF (Variance, Accounted For) is conducted to check the strength of mediation (Wong, 2016; Hair et al., 2014). If the value of VAF is greater than $80 \%$, it shows

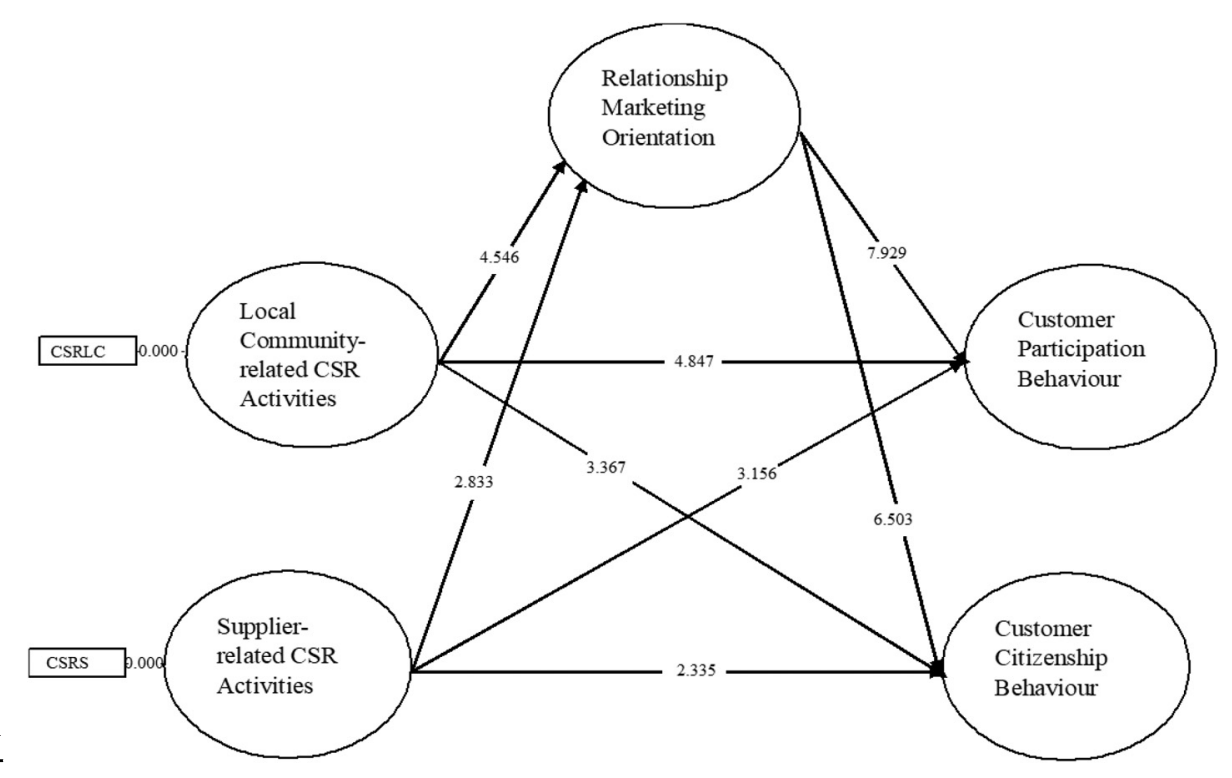

\begin{tabular}{llccccccc}
\hline \multicolumn{8}{c}{ Mediation hypotheses direct effect indirect effect } \\
& & $\beta$ & S.D & $t$-value & $\beta$ & S.D & $t$-value & \\
\hline$H 3 a$ & CSRLC $\rightarrow$ RMO $\rightarrow$ CPB & 0.276 & 0.057 & 4.847 & 0.102 & 0.027 & 3.813 & Supported \\
$H 3 b$ & CSRLC $\rightarrow$ RMO $\rightarrow$ CCB & 0.240 & 0.071 & 3.367 & 0.093 & 0.028 & 3.357 & Supported \\
$H 4 a$ & CSRS $\rightarrow$ RMO $\rightarrow$ CPB & 0.128 & 0.041 & 3.156 & 0.075 & 0.030 & 2.531 & Supported \\
$H 4 b$ & CSRS $\rightarrow$ RMO $\rightarrow$ CCB & 0.114 & 0.049 & 2.335 & 0.069 & 0.028 & 2.494 & Supported
\end{tabular}

Notes: CSLC = Local community-related corporate social responsibility, CSES = Supplier-related corporate social responsibility, RMO = relationship marketing orientation, CPB = customer participation behavior, $\mathrm{CCB}=$ customer citizenship behavior, CSRS = corporate social responsibility supplier 
full mediation while if it falls between the 20 and $80 \%$, it shows partial mediation and if it falls below $20 \%$, it shows no mediation. The values of local community-oriented CSR are 26 and $27 \%$ for customer participation behavior and customer citizenship behavior, respectively. Similarly, the values of supplier-oriented CSR are $37 \%$ for customer participation behavior and customer citizenship behavior. The VAF values for both CSR activities fall between 20 and $80 \%$ which confirms that relationship marketing orientation partially mediates between independent and dependent variables.

\section{Conclusion}

This study aimed to check whether customized CSR activities for local community and suppliers are useful to integrate into the model to generate the value co-creation behavior within the Pakistani banking industry. The present study has proven that local communityoriented activities have a positive role in customer participation behavior and customer citizenship behavior. It shows that CSR is not only important for customers' perception but also works as a driving force for customer value co-creation behavior. This community dimension of CSR is a strategic marketing tool through which banks can add more customers in their pool and advocate their messages in the right direction without additional cost. This finding is aligned with previous studies that show that customized CSR action can shape the behavioral outcomes of customers (Arli and Tjiptono, 2018; Chung et al., 2015; García-Madariaga and Rodríguez-Rivera, 2017). Similarly, supplier-related CSR communications positively affect customer participation behavior and customer citizenship behavior. Focusing on CSR for suppliers, banks can influence the customers' observation because customers are either directly or indirectly the end-users of suppliers' related activities. This study is the first to incorporate the supplier-focused CSR activities in a model to unstructured the customer value co-creation behavior. This study also demonstrated that relationship marketing orientation partially mediates between local community-oriented CSR and customer participation behavior and customer citizenship behavior. RMO also mediates between supplier-oriented CSR and customer participation behavior and customer citizenship behavior. This finding strengthens the outcomes of the study conducted by Luu (2019) that suggested that RMO play a constructive role between CSR and customer value co-creation behavior. With the help of RMO, banks can improve the prospects of qualityoriented contact between customer and service providers in the banking industry of Pakistan.

\subsection{Theoretical implications}

This is the first study that applied stakeholder theory to explore the non-economic value of stakeholders: customer value co-creation behavior. Based on stakeholder theory, most CSR studies strived to assess the behavioral outcomes of the customer concerning the most important stakeholder and missed other imperative stakeholders. Stakeholder theory is also related to the value maximization and the interest of stakeholders, but there are limited number of studies that incorporate importance external stakeholder, i.e.

\begin{tabular}{|c|c|c|c|c|}
\hline VAF & Variables & Indirect effect/total effect & $(\%)$ & Types of mediation \\
\hline & $\mathrm{CSRLC}>\mathrm{RMO}>\mathrm{CPB}$ & $0.102 / 0.390$ & 26 & Partial mediation \\
\hline & $\mathrm{CSRLC}>\mathrm{RMO}>\mathrm{CCB}$ & $0.093 / 0.337$ & 27 & Partial mediation \\
\hline & $\mathrm{CSRS}>\mathrm{RMO}>\mathrm{CPB}$ & $0.075 / 0.199$ & 37 & Partial mediation \\
\hline & $\mathrm{CSRS}>\mathrm{RMO}>\mathrm{CCB}$ & $0.069 / 0.183$ & 37 & Partial mediations \\
\hline
\end{tabular}

\section{Role of relationship marketing orientation}

323 
suppliers to study the customer value co-creation behavior. This study has extended the CSR literature with customer value co-creation behavior under the head of stakeholder theory and service dominant logic. This work contributed into the deficiency of service dominant logic by introducing RMO that explains the interaction between customers and service providers is mandatory for effective value co-creation behavior. Through this lens, it has proved that along with customers, other stakeholder such as local community and suppliers can generate customer value co-creation. Previously stakeholder theory has been used for maximization of shareholders' wealth and did not discuss value co-creation, but the present study applied first time this theory for non-economic value of customer process that lessens the criticism on narrower part of this theory. The findings increase the understanding of value process by connection of three different concepts: CSR, RMO and customer value co-creation behavior.

5.1.1 Managerial/practical implications. This research has several managerial implications for the Pakistani banking industry. The results offer insights for the executives of banking that CSR local community bank do not only contribute to the society but also stimulate customers for active participation. This is because community related CSR activities are closely related to customers, and they can easily notice them due to its tangibility. Similarly, banks must focus on supplier-related CSR activities to build customer value co-creation behavior. This is because supplier-related CSR activities indirectly affect the decision of customers as the end-users of products. Our study exhibits that banks may differentiate and improve the offering by introducing the wide variety of resources that customers and multi-stakeholders are willing to invest jointly and augmenting behaviors. The can also enhance growth, service quality and profit with the help of advocacy behavior of customers through value co-creation behavior. Moreover, in Pakistani banking industry, customers demand productive interaction between service recipients and service providers. The results highlight that with the help of relationship marketing orientation, this sector creates quality-orientated interaction between customers and employees. This new insights will help to minimize the conflict of interest between the customers and the management.

\subsection{Limitations and future research}

This study focused on the external stakeholders, namely, local community and suppliers, for customer value co-creation behavior which limits its generalizability. Second, the results may differ for value co-creation behavior in other service sectors because in banking, interaction is very frequent. Moreover, this study only focused on twin cities: Rawalpindi and Islamabad. In the future, the study can be replicated with additional stakeholders such employees and customers in other industries and the data can be collected in more than two cities.

\section{References}

Abbas, M., Raja, U., Darr, W. and Bouckenooghe, D. (2014), "Combined effects of perceived politics and psychological capital on job satisfaction, turnover intentions, and performance", Journal of Management, Vol. 40 No. 7, pp. 1813-1830.

Abugre, J.B. and Nyuur, R.B. (2015), "Organizations' commitment to and communication of CSR activities: insights from Ghana”, Social Responsibility Journal, Vol. 11 No. 1, pp. 161-178.

Aguilera, R.V., Rupp, D.E., Williams, C.A. and Ganapathi, J. (2007), "Putting the S back in corporate social responsibility: a multilevel theory of social change in organizations", Academy of Management Review, Vol. 32 No. 3, pp. 836-863. 
Ahen, F. and Zettinig, P. (2015), "Critical perspectives on strategic CSR: what is sustainable value co-creation orientation?”, Critical Perspectives on International Business, Vol. 11 No. 1, pp. 92-109.

Ajina, A.S., Japutra, A., Nguyen, B., Syed Alwi, S.F. and Al-Hajla, A.H. (2019), "The importance of CSR initiatives in building customer support and loyalty: evidence from Saudi Arabia”, Asia Pacific Journal of Marketing and Logistics, Vol. 31 No. 3, pp. 691-713.

Anadol, Y., Youssef, M.A. and Thiruvattal, E. (2015), "Consumer reaction towards corporate social responsibility in United Arab Emirates", Social Responsibility Journal, Vol. 11 No. 1, pp. 19-35.

Arena, C., Liong, R. and Vourvachis, P. (2018), "Carrot or stick: CSR disclosures by Southeast Asian companies", sustainability accounting", Sustainability Accounting, Management and Policy Journal, Vol. 9 No. 4, pp. 422-454.

Arifeen, M. (2018), “CSR development and achievements in Pakistan”, Pakistan and Gulf Economist, Vol. 2018.

Arli, D.I. and Tjiptono, F. (2018), "Consumer ethics, religiosity, and consumer social responsibility: are they related”, Social Responsibility Journal, Vol. 14 No. 2, pp. 302-320.

Ashraf, M., Khan, B. and Tariq, R. (2017), "Corporate social responsibility impact on financial performance of bank's: evidence from Asian countries", International Journal of Academic Research in Business and Social Sciences, Vol. 7 No. 4, pp. 618-632.

Badenes-Rocha, A., Ruiz-Mafé, C. and Bigné, E. (2019), "Engaging customers through user-and company-generated content on CSR", Spanish Journal of Marketing - ESIC.

Bae, J., Park, H.H. and Koo, D.M. (2019), "Perceived CSR initiatives and intention to purchase game items: the motivational mechanism of self-esteem and compassion", Internet Research, Vol. 29 No. 2, pp. 329-348.

Bagh, T., Khan, M.A., Azad, T., Saddique, S. and Khan, M.A. (2017), "The corporate social responsibility and firms' financial performance: evidence from financial sector of Pakistan", International Journal of Economics and Financial Issues, Vol. 7 No. 2, pp. 301-308.

Bartley, T. (2007), "Institutional emergence in an era of globalization: the rise of transnational private regulation of labor and environmental conditions", American Journal of Sociology, Vol. 113 No. 2 , pp. 297-351.

Benlemlih, M. and Bitar, M. (2018), "Corporate social responsibility and investment efficiency”, Journal of Business Ethics, Vol. 148 No. 3, pp. 647-671.

Bharti, K., Agrawal, R. and Sharma, V. (2014), "What drives the customer of world's largest market to participate in value co-creation”, Marketing Intelligence and Planning, Vol. 32 No. 4, pp. 413-435.

Bolton, L.E. and Mattila, A.S. (2015), "How does corporate social responsibility affect consumer response to service failure in buyer-seller relationships", Journal of Retailing, Vol. 91 No. 1, pp. 140-153.

Carter, C.R. and Jennings, M.M. (2004), "The role of purchasing in corporate social responsibility: a structural equation analysis", Journal of Business Logistics, Vol. 25 No. 1, pp. 145-186.

Chaudary, S., Zahid, Z., Shahid, S., Khan, S.N. and Azar, S. (2016), "Customer perception of CSR initiatives: its antecedents and consequences", Social Responsibility Journal, Vol. 12 No. 2, pp. 263-279.

Chin, W.W. (1998), "The partial least squares approach to structural equation modelling", Modern Methods for Business Research, Vol. 295 No. 2, pp. 295-336.

Chung, K.H., Yu, J.E., Choi, M.G. and Shin, J.I. (2015), "The effects of CSR on customer satisfaction and loyalty in China: the moderating role of corporate image, journal of economics", Journal of Economics, Business and Management, Vol. 3 No. 5, pp. 542-547. 
De Ruyter, K., De Jong, A. and Wetzels, M. (2009), “Antecedents and consequences of environmental stewardship in boundary-spanning B2B teams", Journal of the Academy of Marketing Science, Vol. 37 No. 4, pp. 470-487.

Dechiara, A. (2012), "SD logic and CSR: the management of social capital for the value creation in SMEs", Journal of Business Market Management, Vol. 5 No. 2, pp. 137-153.

Fatma, M., Khan, I. and Rahman, Z. (2018), "CSR and consumer behavioral responses: the role of customer-company identification”, Asia Pacific Journal of Marketing and Logistics, Vol. 30 No. 2, pp. 460-477.

Fifka, M. (2012), "The development and state of research on social and environmental reporting in global comparison", Journal Für Betriebswirtschaft, Vol. 62 No. 1, pp. 45-84.

Fornell, C. and Larker, D. (1981), "Structural equation modeling and regression: guidelines for research practice", Journal of Marketing Research, Vol. 18 No. 1, pp. 39-50.

García-Madariaga, J. and Rodríguez-Rivera, F. (2017), "Corporate social responsibility, customer satisfaction, corporate reputation, and firms' market value: evidence from the automobile industry", Spanish Journal of Marketing - Esic, Vol. 21 No. 2, pp. 39-53.

Gefen, D., Straub, D. and Boudreau, M.C. (2000), "Structural equation modeling and regression: guidelines for research practice", Communications of the Association for Information Systems, Vol. 4 No. 1, pp. 7-22.

Gohary, A. and Hamzelu, B. (2016), "Modeling customer knowledge management to make value cocreation", Business Information Review, Vol. 33 No. 1, pp. 19-27.

Graafland, J. and van de Van, B. (2006), "Strategic and moral motivation for corporate social responsibility”, Journal of Corporate Citizenship, Vol. 2006 No. 22, pp. 111-123.

Gruen, T.W., Summers, J.O. and Acito, F. (2000), "Relationship marketing activities, commitment, and membership behaviors in professional associations", Journal of Marketing, Vol. 64 No. 3, pp. 34-49.

Gummesson, E. (1999), Total Relationship Marketing: Rethinking Marketing Management from 4Ps to 30 Rs, Butterworth Heinemann, Oxford.

Hair, J.F., Jr, Sarstedt, M., Ringle, C.M. and Gudergan, S.P. (2017), Advanced Issues in Partial Least Squares Structural Equation Modeling, Sage Publications.

Hair, J.F., Jr, Sarstedt, M., Hopkins, L. and Kuppelwieser, V.G. (2014), "Partial least squares structural equation modeling (PLS-SEM)”, European Business Review, Vol. 26 No. 2, pp. 106-121.

Halkias, D., Rashid, M., Abdeljawad, I., Ngalim, S.M. and Hassan, M.K. (2013), "Customer-centric corporate social responsibility", Management Research Review, Vol. 36 No. 4.

Harrison, J.S. and Wicks, A.C. (2013), "Stakeholder theory, value, and firm performance", Business Ethics Quarterly, Vol. 23 No. 1, pp. 97-124.

Hietbrink, J.J.C., Berens, G. and Van Rekom, J. (2010), "Corporate social responsibility in a business purchasing context: the role of CSR type and supplier product share size", Corporate Reputation Review, Vol. 13 No. 4, pp. 284-300.

Ida, E. (2017), "The role of customers' involvement in value co-creation behaviour is value co-creation the source of competitive advantage", Journal of Competitiveness, Vol. 9 No. 3, pp. 51-66.

Ismail, M., Alias, S.N. and Mohd Rasdi, R. (2015), "Community as stakeholder of the corporate social responsibility programme in Malaysia: outcomes in community development", Social Responsibility Journal, Vol. 11 No. 1, pp. 109-130.

Jayachandran, S., Sharma, S., Kaufman, P. and Raman, P. (2005), "The role of relational information processes and technology use in customer relationship management", Journal of Marketing, Vol. 69 No. 4, pp. 177-192.

Kamboj, S. and Rahman, Z. (2017), "Measuring customer social participation in online travel communities: scale development and validation", Journal of Hospitality and Tourism Technology, Vol. 8 No. 3, pp. 432-464. 
Karaosmanoglu, E., Altinigne, N. and Isiksal, D.G. (2016), "CSR motivation and customer extra-role behavior: moderation of ethical corporate identity", Journal of Business Research, Vol. 69 No. 10, pp. 4161-4167.

Khan, S., Baig, N., Awan, A.W. and Ullah, M. (2014), "Do corporate social responsibility initiatives favorable for banks", Customer's Perceptions.

Knox, S. and Gruar, C. (2007), "The application of stakeholder theory to relationship marketing strategy development in a non-profit organization”, Journal of Business Ethics, Vol. 75 No. 2, pp. 115-135.

Kolk, A. and Van Tulder, R. (2002), "Child labor and multinational conduct: a comparison of international business and stakeholder codes", Journal of Business Ethics, Vol. 36 No. 3, pp. 291-301.

KPMG (2015), “The KPMG survey of corporate responsibility reporting 2015”, Retrieved from KPMG Website: www.kpmg.com/cn/en/issuesandinsights/articlespublications/pages/kpmg-survey-ofcorporate-responsibility-reporting-2015-o-201511.aspx

KPMG (2016), "Carrots and sticks: global trends in sustainability reporting regulation and policy", available at: www.carrotsandsticks.net (accessed 19May 2017).

Krejcie, R.V. and Morgan, D.W. (1970), "Determining sample size for research activities”, Educational and Psychological Measurement, Vol. 30 No. 3, pp. 607-610.

Kumar, A., Mangla, S.K., Luthra, S., Rana, N.P. and Dwivedi, Y.K. (2018), "Predicting changing pattern: building model for consumer decision making in digital market", Journal of Enterprise Information Management, Vol. 31 No. 5, pp. 674-703.

Laczniak, G.R. and Murphy, P.E. (2006), "Normative perspectives for ethical and socially responsible marketing", Journal of Macromarketing, Vol. 26 No. 2, pp. 154-177.

Lee, J. and Lee, Y. (2018), "Effects of multi-brand company's CSR activities on purchase intention through a mediating role of corporate image and brand image", Journal of Fashion Marketing and Management: An International Journal, Vol. 22 No. 3, pp. 387-403.

Lee, E.M. and Yoon, S.J. (2018), "The effect of customer citizenship in corporate social responsibility (CSR) activities on purchase intention: the important role of the CSR image", Social Responsibility Journal, Vol. 14 No. 4, pp. 753-763.

Lee, M.J., Singh, N. and Chan, E.S. (2011), "Service failures and recovery actions in the hotel industry: a text-mining approach", Journal of Vacation Marketing, Vol. 17 No. 3, pp. 197-207.

Li, J., He, H., Liu, H. and Su, C. (2017), "Consumer responses to corporate environmental actions in China: an environmental legitimacy perspective", Journal of Business Ethics, Vol. 143 No. 3, pp. 589-602.

Longo, M., Mura, M. and Bonoli, A. (2005), "Corporate social responsibility and corporate performance: the case of italian SMEs", Corporate Governance: The International Journal of Business in Society, Vol. 5 No. 4, pp. 28-42.

Luu, T.T. (2019), "CSR and customer value co-creation behavior: the moderation mechanisms of servant leadership and relationship marketing orientation”, Journal of Business Ethics, Vol. 155 No. 2, pp. 379-398.

McColl-Kennedy, J.R., Vargo, S.L., Dagger, T.S., Sweeney, J.C. and Kasteren, Y.V. (2012), "Health care customer value cocreation practice styles", Journal of Service Research, Vol. 15 No. 4, pp. 370-389.

Maignan, I., Hillebrand, B. and McAlister, D. (2002), "Managing socially-responsible buying: How to integrate non-economic criteria into the purchasing process", European Management Journal, Vol. 20 No. 6, pp. 641-648.

Mainardes, E.W., Teixeira, A. and da Silveira Romano, P.C. (2017), "Determinants of co-creation in banking services", International Journal of Bank Marketing, Vol. 35 №. 2. 
Maloni, M.J. and Brown, M.E. (2006), "Corporate social responsibility in the supply chain: an application in the food industry", Journal of Business Ethics, Vol. 68 No. 1, pp. 35-52.

Mandhachitara, R. and Poolthong, Y. (2011), "A model of customer loyalty and corporate social responsibility”, Journal of Services Marketing, Vol. 25 No. 2, pp. 122-133.

Mangi, N.A. (2012), "The secret strength of Pakistan's economy”, Bloomberg Business Week, Vol. 5.

Maon, F., Swaen, V. and Lindgreen, A. (2017), "One vision, different paths: an investigation of corporate social responsibility initiatives in Europe", Journal of Business Ethics, Vol. 143 No. 2, pp. 405-422.

Marquina Feldman, P. and Vasquez-Parraga, A.Z. (2013), "Consumer social responses to CSR initiatives versus corporate abilities”, Journal of Consumer Marketing, Vol. 30 No. 2, pp. 100-111.

Memon, M.A., Cheah, J., Ramayah, T., Ting, H. and Chuah, F. (2018), "Mediation analysis issues and recommendations", Journal of Applied Structural Equation Modeling, Vol. 4 No. 2, pp. 1-9.

Mohammed, A. and Al-Swidi, A. (2019), "The influence of CSR on perceived value, social media and loyalty in the hotel industry", Spanish Journal of Marketing - ESIC.

Morgan, R.M. and Hunt, S.D. (1994), “The commitment-trust theory of relationship marketing”, Journal of Marketing, Vol. 58 No. 3, pp. 20-38.

Mujahid, M. and Abdullah, A. (2014), "Impact of corporate social responsibility on firm's financial performance and shareholders wealth", European Journal of Business and Management, Vol. 6 No. 31, pp. 181-187.

Oberseder, M., Schlegelmilch, B.B., Murphy, P.E. and Gruber, V. (2014), "Consumers' perceptions of corporate social responsibility: scale development and validation", Journal of Business Ethics, Vol. 124 No. 1, pp. 101-115.

Pakistan Bureau of Statistics (2017), Province Wise Provisional Results of Census, Pakistan Bureau of Statistics, Islamabad.

Payne, A. and Frow, P. (2017), "Relationship marketing: looking backwards towards the future", Journal of Services Marketing, Vol. 31 No. 1, pp. 11-15.

Payne, A., Ballantyne, D. and Christopher, M. (2005), "Relationship marketing: a stakeholder approach", European Journal of Marketing, Vol. 39 Nos 7/8, pp. 155-171.

Pérez, A. and Del Bosque, I.R. (2013), "Measuring CSR image: three studies to develop and to validate a reliable measurement tool”, Journal of Business Ethics, Vol. 118 No. 2, pp. 265-286.

Pérez, A. and Rodriguez del Bosque, I. (2015), "Corporate social responsibility and customer loyalty: exploring the role of identification, satisfaction and type of company", Journal of Services Marketing, Vol. 29 No. 1, pp. 15-25.

Pérez, A. and Rodríguez del Bosque, I. (2017), "Personal traits and customer responses to CSR perceptions in the banking sector", International Journal of Bank Marketing, Vol. 35 No. 1, pp. 128-146.

Planken, B., Nickerson, C. and Sahu, S. (2013), “CSR across the globe: Dutch and Indian consumers' responses to CSR", International Journal of Organizational Analysis, Vol. 21 No. 3, pp. 357-372.

ProPakistani (2019), "ProPakistani. Pakistani banking sector in 2018 [roundup]".

Raja, U., Johns, G. and Ntalianis, F. (2004), "The impact of personality on psychological contracts", Academy of Management Journal, Vol. 47 No. 3, pp. 350-367.

Rialti, R., Caliandro, A., Zollo, L. and Ciappei, C. (2018), "Co-creation experiences in social media Brand communities: analyzing the main types of co-created experiences", Spanish Journal of Marketing Esic, Vol. 22 No. 2, pp. 122-141.

Royle, J. and Laing, A. (2014), "The digital marketing skills gap: developing a digital marketer model for the communication industries", International Journal of Information Management, Vol. 34 No. 2, pp. 65-73. 
Ruiz-Alba, J., Vallespín, M. and González-Porras, J. (2014), "El voluntariado corporativo y sus efectos sobre la satisfacción laboral y el compromiso en empresas familiares de andalucía. Revista de empresa familiar", European Journal of Family Business, Vol. 4 No. 1, pp. 45-58.

Sanclemente-Téllez, J.C. (2017), "Marketing and corporate social responsibility (CSR). Moving between broadening the concept of marketing and social factors as a marketing strategy", Spanish Journal of Marketing - Esic, Vol. 21 No. 21, pp. 4-25.

Sen, S., Bhattacharya, C.B. and Korschun, D. (2006), "The role of corporate social responsibility in strengthening multiple stakeholder relationships: a field experiment", Journal of the Academy of Marketing Science, Vol. 34 No. 2, pp. 158-166.

Shahbaz, R. (2017), 6th Census Findings:207 Million and Counting, The Express Tribune, Islamabad.

Sin, L.Y., Tse, A.C., Yau, O.H., Chow, R.P. and Lee, J.S. (2005), "Market orientation, relationship marketing orientation, and business performance: the moderating effects of economic ideology and industry type", Journal of International Marketing, Vol. 13 No. 1, pp. 36-57.

Skudiene, V. and Auruskeviciene, V. (2012), "The contribution of corporate social responsibility to internal employee motivation", Baltic Journal of Management, Vol. 7 No. 1, pp. 49-67.

State Bank of Pakistan (2016), Access to Finance Part 6 of a 15 Part Series, State Bank of Pakistan, Islamabad.

Syed, M.A. and Butt, S.A. (2017), "Financial and non-financial determinants of corporate social responsibility: empirical evidence from Pakistan”, Social Responsibility Journal, Vol. 13 No. 4, pp. 780-797.

Terrero-De La Rosa, A., Santiago-Ortega, R., Medina-Rivera, Z. and Berrios-Lugo, J. (2017), “Corporate social responsibility practices and programs as a key strategic element in organizational performance", corporate social responsibility and corporate governance developments", in Corporate Governance and Responsibility, Vol. 11 No. 3, pp. 223-247.

Tingchi Liu, M., Anthony Wong, I., Rongwei, C. and Tseng, T.H. (2014), "Do perceived CSR initiatives enhance customer preference and loyalty in casinos", International Journal of Contemporary Hospitality Management, Vol. 26 No. 7, pp. 1024-1045.

Tse, A.C., Sin, L.Y., Yau, O.H., Lee, J.S. and Chow, R. (2004), “A firm's role in the marketplace and the relative importance of market orientation and relationship marketing orientation", European Journal of Marketing, Vol. 38 Nos 9/10, pp. 1158-1172. No

Urbach, N. and Ahlemann, F. (2010), "Structural equation modeling in information systems research using partial least squares", Journal of Information Technology Theory and Application, Vol. 11 No. 2, pp. 5-40.

Van Tonder, E. and Petzer, D.J. (2018), "Perspectives on "other" customers' roles in citizenship behavior”, International Journal of Bank Marketing, Vol. 36 No. 2, pp. 393-408.

Vargo, S.L. and Lusch, R.F. (2004), "The four service marketing myths: remnants of a goods-based, manufacturing model", Journal of Service Research, Vol. 6 No. 4, pp. 324-335.

Vargo, S.L. and Lusch, R.F. (2008), "Service-dominant logic: continuing the evolution", Journal of the Academy of Marketing Science, Vol. 36 No. 1, pp. 1-10, doi: 10.1007/s11747-007-0069-6

Vargo, S.L., Lusch, R.F. (2011), "It's all B2B... and beyond: toward a systems perspective of the market", Industrial Marketing Management, Vol. 40 No. 2, pp. 181-187.

Vargo, S.L. and Lusch, R.F. (2014), "Evolving to a new dominant logic for marketing", In the ServiceDominant Logic of Marketing, pp. 21-46.

Wagner, A. (2017), "The failure of corporate social responsibility provisions within international trade agreements and export credit agencies as a solution", BU Int'l LJ, Vol. 35, p. 195.

Watts, P. (2000), Corporate Social Responsibility: making Good Business Sense, World Business Council for Sustainable Development. 
SJME

24,3

Wong, K.K.K. (2016), "Mediation analysis, categorical moderation analysis, and higher-order constructs modeling in partial least squares structural equation modeling PLS-SEM", Marketing Bulletin, Vol. 26.

Yi, Y. and Gong, T. (2013), "Customer value co-creation behavior: Scale development and validation", Journal of Business Research, Vol. 66 No. 9, pp. 1279-1284.

Zhang, T., Kandampully, J. and Bilgihan, A. (2015), "Motivations for customer engagement in online coinnovation communities (OCCs) a conceptual framework", Journal of Hospitality and Tourism Technology, Vol. 6 No. 3, pp. 311-328.

Zhao, Y., Yan, L. and Keh, H.T. (2018), "The effects of employee behaviors on customer participation in the service encounter: the mediating role of customer emotions", European Journal of Marketing, Vol. 52 No. 5/6, pp. 1203-1222.

\section{Corresponding author}

Muhammad Mubushar can be contacted at: mubushar.raja@gmail.com

For instructions on how to order reprints of this article, please visit our website: 